\title{
Treatment of Bleeding in Patients with Platelet Disorders: Is There a Place for Recombinant Factor VIla?
}

\section{Yves Laurian}

Novo Nordisk Pharmaceutique SA, Boulogne-Billancourt, France

\section{Key Words}

Thrombocytopenia $\cdot$ Inherited thrombocytopathia . Glanzmann thrombasthenia $\cdot$ Bleeding $\cdot$ rFVIla

\begin{abstract}
The mechanism of action of recombinant factor Vlla (rFVIla), i.e. increased thrombin generation on the membrane of activated platelets, as well as the results from in vitro and ex vivo models of thrombocytopenia or inherited thrombocytopathia may support some potential of rFVIla in thrombocytopenia/thrombocytopathia. rFVIIa was reported as effective to stop or to decrease bleeding in few patients with severe thrombocytopenia resistant to platelet transfusions; however data are still scarce and clinical studies are really needed to define efficacy/safety ratio as well as optimal treatment regimen in this potential indication. Some data in patients with Glanzmann thrombasthenia (GT) may support the use of rFVIla outside its primary indication in the cases in which there is no real treatment alternative (GT patients with antibodies to GP Ilb-IIla or with platelet refractoriness).
\end{abstract}

Copyright $\odot 2002$ S. Karger AG, Basel

\begin{tabular}{ll}
\hline KARGER & ○ 2002 S. Karger AG, Basel \\
Fax +41 61306 12 34 & 1424-8832/02/0327-0037\$18.50/0 \\
$\begin{array}{l}\text { E-Mail karger@karger.ch } \\
\text { www.karger.com }\end{array}$ & $\begin{array}{l}\text { Accessible online at: } \\
\text { www.karger.com/journals/pht }\end{array}$
\end{tabular}

\section{Introduction}

Recombinant factor VIIa (rFVIIa; NovoSeven ${ }^{\circledR}$ ) was approved for the treatment of bleeding episodes and the prevention of bleeding during surgery in patients with haemophilia and inhibitors and in patients with acquired haemophilia [1-5]. In this indication, rFVIIa demonstrated an excellent efficacy and safety profile [6, 7]. rFVIIa is produced without any human derivatives (no risk of transmission of viruses or other transmissible agents from human origin; no risk of anamnestic rise of the inhibitor titre) $[1,5]$. Optimal results were observed when rFVIIa is used as first-line therapy $[4,8,9]$ and with optimal treatment regimen [1-3].

\section{Mode of Action}

The proposed mechanism of action of rFVIIa in patients with haemophilia is an increased thrombin generation on the membrane of the activated platelets localized at the site of bleeding [10-12] allowing a better fibrin clot less prone to fibrinolysis and a better activation of factor XIII and of thrombin activable fibrinolysis inhibitor (TAFI). Decreased thrombin generation was previously reported in patients with thrombocytopenia, with Glanzmann thrombasthenia (GT) and with Bernard-Soulier

Yves Laurian, MD

Novo Nordisk Pharmaceutique SA

32 , rue de Bellevue

F-92273 Boulogne-Billancourt (France)

Fax +331468459 53, E-Mail yvla@novonordisk.com 
syndrome (BSS). This raises the question whether rFVIIa could be a potential candidate as a new haemostatic drug for bleeding in these patients. Some in vitro/ex vivo data $[13-14]$ as well as some case reports $[15,16]$ may support rFVIIa as a drug with potentiality in platelet disorders.

\section{Thrombocytopenia}

High dose of recombinant factor VIIa was reported

- to shorten significantly the microvascular bleeding time in thrombocytopenic rabbits

- to increase the initial thrombin generation, resulting in faster platelet activation in an in vitro model of severe thrombocytopenia [13]

- to enhance fibrin deposition in a chamber under flow conditions using thrombocytopenic blood [14].

However, high dose of rFVIIa did not increase, in the in vitro model of thrombocytopenia, the rate of thrombin generation which remains very low when compared to normal [13] and there was no improvement of platelet deposition on subendothelium under flow conditions [14].

A study was undertaken in 74 patients with moderate to severe thrombocytopenia related to either impaired platelet production or immune destruction to evaluate the safety of rFVIIa in patients with thrombocytopenia but normal coagulation factors [15]. Each patient received a single dose of 50 and $/$ or $100 \mu \mathrm{g} / \mathrm{kg}$. A total of 111 injections were given. The clinical tolerance was excellent, except one anaphylactoid reaction in a patient with previous history of such reactions with other drugs. A reduction of the bleeding time was found in 55/105 cases after a single dose of rFVIIa $(50$ or $100 \mu \mathrm{g} / \mathrm{kg})$. This reduction was significantly more pronounced when the platelet count exceeded $20 \times 10^{9} / 1$. However, these results must be discussed with caution since no venostasis pressure was applied in patients with impaired platelet production (47 patients; 66 cases). Ten minor/moderate bleeds (neck incision, epistaxis, uterine bleed) were treated with a single dose of rFVIIa (50 or $100 \mu \mathrm{g} / \mathrm{kg}$ ) in 8 patients with moderate to severe thrombocytopenia (3 patients with platelets $\leq 10 \times 109 / 1 ; 3$ patients with $11-20$ and 2 patients $>20-33$ ) [15]. Bleeding stopped in 7 cases and slowed down or almost ceased in the last 3 cases. There was no clear correlation between shortening of bleeding time and stop of bleeding. Since then no result of clinical trials have been published. Only case stories have appeared in the literature $[17,18]$.

$38 \quad$ Pathophysiol Haemost Thromb 2002;32(suppl 1):37-40
rFVIIa has some potential in thrombocytopenia, but many questions remain unsolved:

- Efficacy/safety ratio and cost-effectiveness?

- Minimal number of platelets required to get efficacy of rFVIIa?

- Treatment regimen (dose of rFVIIa per injection; number of doses to stop the bleed; interval between doses)?

- Need for additional doses to avoid recurrence of bleeding when stopped?

- Use of rFVIIa alone or in addition to platelets transfusion when very low platelet count?

- Benefit of addition of platelets transfusion in case of complete platelet refractoriness with no circulating platelets?

Only a full clinical development with randomised studies may answer these questions and allow to evaluate the possible place of rFVIIa in patients with bleeding related to severe thrombocytopenia.

\section{Inherited Thrombocytopathia}

Inherited platelet function disorders with bleeding tendency are very rare, including Glanzmann thrombasthenia (GT), Bernard-Soulier syndrome (BSS), pseudo-Willebrand and few other diseases [5]. The treatment of bleeding or prevention of bleeding for surgery/invasive procedure is based on platelet transfusion when local measures and antifibrinolytic drug failed. However platelet transfusions may be responsible for development of antibodies to GP IIb-IIIa, GP Ib or HLA with high-risk of future platelet refractoriness $[19,20]$. Moreover platelet concentrates have a low but real residual risk of viral contamination.

Decreased thrombin generation was previously reported in patients with GT and in patients with BSS. rFVIIa was reported to increase local fibrin deposition as well as partially restore platelet aggregates in GLZ as well as in BSS [14]. These data may support rFVIIa as a potential haemostatic candidate in these patients.

rFVIIa was reported to stop or prevent bleeding in patients with GLZ with or without antibody to GP IIbIIIa [16, 19-27]. The result of a pilot study was published [19] on the use of rFVIIa to treat 24 bleeding episodes and to prevent bleeding during one bilateral herniorrhaphy in 4 patients with GT. rFVIIa was administered at 89 to $116 \mu \mathrm{g} / \mathrm{kg}$ per injection every $2 \mathrm{~h}$, in association with antifibrinolytic drugs. Bleeding stopped with rFVIIa in all, but one case and there was no abnormal bleeding during and after the surgical procedure. In two cases, the 
bleeding recurred 36 and $63 \mathrm{~h}$ after discontinuation of rFVIIa, but the two episodes were successfully treated with additional doses of rFVIIa. Data on the use of rFVIIa in patients with GLZ were collected in an international data collection $[26,27]$. In the last presentation of these data [27], intention to treat analysis with rFVIIa showed efficacy in all 11 evaluable invasive/surgical procedures and in $73 \%$ of the 55 bleeding episodes (fig. 1).

Taking into account these data [16, 19-27], rFVIIa may be particularly helpful in GT patients with antibodies to GP IIb-IIIa or to HLA or in patients with platelet inefficacy, since treatment alternatives are scarce and may not be efficacious [19, 20, 26, 27].

In other inherited thrombocytopathia, a single patient with BSS [28] and one with pseudo von Willebrand disease [29] were reported to be treated efficiently with rFVIIa.

\section{Acquired Thrombocytopathia}

Recombinant FVIIa was reported as efficient for few bleeds related to uremic syndrome $[30,31]$ and to acquired thrombocytopathia related to myelodysplasic syndrome [32], but no other data have been yet published in peer-reviewed paper on acquired thrombocytopathia.

\section{Discussion}

rFVIIa is a drug with real potentiality in platelet disorders. Clinical data may support the use of rFVIIa, outside its primary indication, in GT patients with antibodies to

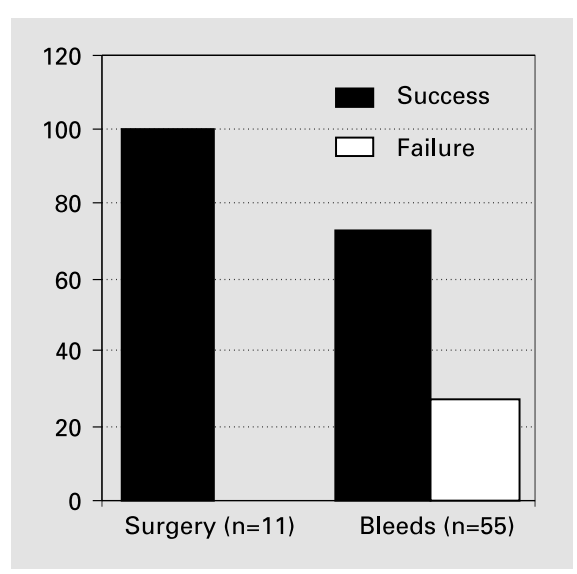

Fig. 1. Intention to treat with recombinant factor VIIa in patients with Glanzmann thrombasthenia.
GP IIb-IIIa or to HLA or with platelet inefficacy due to the absence of real alternative treatment $[19,20,22,26$, 27]. For patients with thrombocytopenia, clinical data are still too scarce and there is a major need for full clinical development, including randomised double-blind study whenever possible, to demonstrate efficacy and safety of rFVIIa as well as cost-efficacy. Clinical development was recently started. While awaiting the results of such studies, some question the use of rFVIIa outside its indication in cases of persistent life-threatening bleeds despite adequate platelet transfusions $[17,18]$; however there is no data yet to support any treatment regimen as well as the use or not of concomitant platelet transfusions.

\section{References}

1 Hedner U: NovoSeven ${ }^{\circledR}$ as a universal hemostatic agent. Blood Coagul Fibrinolysis 2000; 11(suppl 1):S107-S111.

2 Shapiro A, Gilchrist GS, Hoots WK, Cooper HA, Gastineau DA: Prospective, randomised trial of two doses of rFVIIa (Novoseven) in haemophilia patients with inhibitors undergoing Surgery. Thromb Haemost 1998;80:773778.

3 Key NS, Aledort LM, Beardsley D, Cooper HA, Davignon G, Ewenstein BM, Gilchrist GS, Gill JC, Glader B, Hoots WK, Kisker CT, Lusher JM, Rosenfield CG, Shapiro AD, Smith $\mathrm{H}$, Taft E: Home treatment of mild to moderate bleeding episodes using recombinant factor VIIa (NovoSeven) in haemophiliacs with inhibitors. Thromb Haemost 1998;80:912-918.
4 Hay CRM, Negrier C, Ludlam CA: The treatment of bleeding in acquired haemophilia with recombinant factor VIIa: A multicentre study. Thromb Haemost 1997;78:1463-1467.

5 Poon M.C: Use of recombinant factor VIIa in hereditary bleeding disorders. Curr Opin Hematol 2001;8:312-318.

6 Roberts HR: Clinical experience with activated factor VII: focus on safety aspects. Blood Coagul Fibrinolysis 1998;9(suppl 1):S115-S118.

7 Aledort LM: Recombinant factor VIIa is a panhemostatic agent. Thromb Haemost 2000;83: 637-638.

8 Lusher JM: Acute hemarthroses: the benefits of early versus late treatment with recombinant activated factor VII. Blood Coagul Fibrinolysis 2000;11(suppl 1):S45-S48.
9 Lusher JM: Recombinant activated factor VII for treatment of intramuscular haemorrhages: A comparison of early versus late treatment. Blood Coagul Fibrinolysis 1998;9(suppl 1): S111-S114.

10 Monroe DM, Hoffman M, Oliver JA, Roberts HR: Platelet activity of high-dose factor VIIa is independent of tissue factor. Br J Haematol 1997;99:542-547.

11 Hoffmann M, Monroe DM, Roberts HR: Activated factor VII activates factors IX and X on the surface of activated platelets: Thoughts on the mechanism of action of high-dose activated factor VII. Blood Coagul Fibrinolysis 1998;9 (suppl 1):S61-S65. 
12 Hoffman M, Monroe DM: A cell-based model of hemostasis. Thromb Haemost 2001;85:958965.

13 Kjalke M, Ezban M, Monroe DM, Hoffmann M, Roberts HR, Hedner U: High-dose factor VIIa increases initial thrombin generation and mediates faster platelet activation in thrombocytopenia-like conditions in a cell-based model system. Br J Haematol 2001;1 14:114-120.

14 Galan M, Reverter JC, Pino M, Vinas M, Lozano M, Ordinas A, Escolar G: Increased local procoagulant action: A mechanism contributing to the favourable hemostatic effect of activated recombinant factor VII ( $\mathrm{rFVIIa)} \mathrm{in} \mathrm{quan-}$ ti- and qualitative disorders of platelet function. XVIII Congress of the International Society of Thrombosis and Haemostasis, Paris, France, 6-12 July 2001 (abstract).

15 Kristensen J, Killander A, Hippe E, Helleberg C, Ellegard J, Holm M, Kutti J, Mellqvist UH, Johansson JE, Glazer S, Hedner U: Clinical experience with recombinant factor VIIa in patients with thrombocytopenia. Haemostasis 1996;26(suppl 1):159-164.

16 Tengborn L, Petruson B: A patient with Glanzmann thrombasthenia and epistaxis successfully treated with recombinant factor VII. Thromb Haemost 1996;75:981-982.

17 Vidarsson B, Önundarson PT: Recombinant factor VIIa for bleeding in refractory thrombocytopenia. Thromb Haemost 2000;83:634635.

18 Blatt J, Gold SH, Wiley JM, Monahan PE, Cooper HC, Harvey D: Off-label use of recombinant factor VIIa in patients following bone marrow transplantation. Bone Marrow Transplantation 2001;28:405-407.
19 Poon M-C, Demers C, Jobin F, Wu JWY: Recombinant factor VIIa is effective for bleeding and surgery in patients with Glanzmann thrombasthenia. Blood 1999;94:3951-3953.

20 d'Oiron R, Ménart C, Trzeciak C, Nurden P, Fressinaud E, Dreyfus M, Laurian Y, Négrier $\mathrm{C}$ : Use of recombinant factor VIIa in 3 patients with inherited type I Glanzmann's thrombasthenia undergoing invasive procedures. Thromb Haemost 2000;83:644-647.

21 Wielenga JJ, Siebel Y, van Buuren HR, Berends FJ, Schipperus MER, van Vliet HDDM, Kappers MC: Use of recombinant factor VIIa and HLA matched platelets to prevent bleeding during and after major surgery in a patient with Glanzmann thromboasthenia. Haemophilia 1998;4: XXIIIth Congress of the World Federation of Hemophilia (abstract).

22 Patel RK, Savidge GF, Rangarajan S: Use of recombinant factor VIIa for post-operative haemorrhage in a patient with Glanzmann's thrombasthenia and human leucocyte antigen antibodies. Br J Haematol 2001;1 14:245-246.

23 Ancliff P, Liesner R, Khair K, Hann I: The use of recombinant factor VIIa in a patient with severe Glanzmann's thrombasthenia to facilitate insertion of a Port-a-Cath ${ }^{\circledR}$. Blood Coagul Fibrinolysis 1999;10:447-448.

24 Chuansumrit A, Sangkapreecha C, Hathirat P: Successful epistaxis control in a patient with Glanzmann thrombasthenia by increased bolus injection dose of recombinant factor VIIa. Thromb Haemost 1999;82:1178.

25 Musso R, Cultrera D, Russo M, Giuffrida G, Venturino L, Ferlito C, Salerni S, Azzaro MP, Incatasciato D: Recombinant activated factor VII as haemostatic agent in Glanzmann's thromboastenia. Thromb Haemost 1999 (suppl), XVIIth Congress of the International Society on Thrombosis and Haemostasis (abstract).
26 Poon MC, d'Oiron R \& the International Registry on Recombinant Factor VIIa and Congenital Platelet Disorders Group Recombinant activated factor VII (Novoseven ${ }^{\circledR}$ ) in the treatment of platelet-related bleeding disorders. Blood Coagul Fibrinolysis 2000;11(suppl 1): S55-S68.

27 Poon MC, Katsarou O, Huth-Kuehne A, Petrini P, Hann I, Demers C, Fressinaud E, Tengborn L, Thomas A, Nohe N, Strauss G, Négrier C, Makris PE, Molho P, Pautard B, Berger C, Beurrier P, Wilde J, Devecioglu O, Peters M, d'Oiron R: Recombinant factor VIIa in congenital platelet bleeding disordersAmerican Society of Hematology 2000, 1-5 December, San Francisco. Blood; 96(suppl 1):256a (abstract).

28 Peters M, Heijboer H: Treatment of a patient with Bernard-Soulier syndrome and recurrent nosebleeds with recombinant factor VIIa. Thromb Haemost 1998;80:352.

29 Fressinaud E, Sigaud-Fiks M, Le Boterff C, Piot B: Use of recombinant factor VIIa (NovoSeven ${ }^{\circledR}$ ) for dental extraction in a patient affected by platelet-type (pseudo-) von Willebrand disease. Haemophilia 1998;4: XXIIIth Congress of the World Federation of Hemophilia (abstract)

30 Revesz T, Arets B, Bierings M, van den Bos C, Duval E: Recombinant factor VIIa in severe uremic bleeding. Thromb Haemost 1998;80: 353.

31 Moisescu E, Ardelean L, Simion I, Muresan A, Ciupan R: Recombinant factor VIIa treatment of bleeding associated with acute renal failure. Blood Coagul Fibrinolysis 2000;11:575-577.

32 Meijer K, Sieders E, Slooff JH, de Wolf JTM, van der Meer J: Effective treatment of severe bleeding due to acquired thrombocytopathia by single dose administration of activated recombinant factor VII. Thromb Haemost 1998; 80:204-205. 